\title{
Ewaluacja sytuacji finansowo-majątkowej polskich gospodarstw rolnych w latach 2004-2014
}

\section{Wstęp}

Gospodarstwo rolne jest podstawową oraz najstarszą formą prowadzenia działalności gospodarczej w rolnictwie. Globalizacja niesie za sobą konieczność dostosowania się gospodarstw rolnych do zmieniającego się otoczenia poprzez realizację przedsięwzięć restrukturyzacyjnych mających na celu obniżkę kosztów swojej działalności i zwiększenie swojej innowacyjności. Podejmowane działania odbijają się na sytuacji finansowo-majątkowej podmiotów gospodarczych. Rozwój gospodarstw rolnych ma szczególne znaczenie dla rozwoju gospodarczego państw, w których sektor rolnictwa odgrywa ważną rolę w tworzeniu miejsc pracy oraz stanowi bazę surowcową dla ludności i przemysłu [Sadowski 2009].

Podstawowym celem artykułu jest ocena rozwoju sytuacji finansowo-majątkowej polskich gospodarstw rolnych. W tym kontekście postawiono następująca hipotezę badawczą: „Gospodarstwa rolne o wielkości ekonomicznej powyżej 0,5 mln EUR charakteryzują się korzystniejszą sytuacją finansowo-majątkową oraz wykazują większą dynamikę rozwoju w porównaniu z mniejszymi podmiotami". W podjętych analizach wykorzystano podejście indukcyjne. Początkowe rozważania poświęcono teoretycznym zagadnieniom związanym z gospodarstwami rolnymi i ich sytuacją finansowo-majątkową. Właściwa część opracowania poświęcona została empirycznej weryfikacji hipotezy głównej. Wyznaczono wskaźniki analityczne i syntetyczne dla gospodarstw rolnych, a następnie dokonano ich oceny i sformułowano wnioski końcowe. 


\section{Gospodarstwo rolne - definicja, determinanty rozwoju}

Termin gospodarstwo rolne jest wieloznaczny i może być rozpatrywany $z$ różnych punktów widzenia. W kontekście rozważań podjętych w niniejszym opracowaniu należy rozróżnić pojęcie gospodarstwa rolnego od przedsiębiorstwa. W literaturze przedmiotu poświęconej ekonomice i organizacji rolnictwa za gospodarstwo rolne uważa się „,celowo zorganizowany, mający własne kierownictwo, zespół ludzi, ziemi i pozostałych niezbędnych do procesu produkcyjnego środków produkcji, który zajmuje się produkcją roślinną, roślinną i zwierzęca, a niekiedy roślinną, zwierzęcą i przetwórstwem rolnym" [Rychlik i Kosieradzki 1978]. Z ekonomicznego punktu widzenia gospodarstwo rolne to „zespół ludzi, ziemi i innych środków produkcji, których zadaniem jest wytwarzanie artykułów rolnych przez uprawę roślin oraz chów zwierząt" [Zegar 2012]. Gospodarstwo rolne związane jest $\mathrm{z}$ procesem produkcji, a więc z przetwarzaniem nakładów w produkcję rolniczą. Gospodarstwo rolne stanowi zatem wyodrębnioną pod względem organizacyjnym jednostkę, która stanowi zespół trzech czynników produkcji: pracy, ziemi i kapitału. Zgodnie z polskim kodeksem cywilnym (kc) gospodarstwem rolnym są: ,grunty rolne wraz z gruntami leśnymi, budynkami lub ich częściami, urządzeniami i inwentarzem, jeżeli stanowią lub mogą stanowić zorganizowaną całość gospodarcza, oraz prawami związanymi z prowadzeniem gospodarstwa rolnego" [Dz.U. 2015, poz. 380, art. 55].

Z kolei przedsiębiorstwo rolne jest jednostką wyodrębnioną pod względem ekonomicznym, prawnym i organizacyjnym, która prowadzi działalność produkcyjną przeznaczoną na rynek [Budzinowski i Suchoń 2015]. Stanowi ono zgodnie z art. $55 \mathrm{kc}$,zorganizowany zespół składników niematerialnych i materialnych przeznaczonych do prowadzenia działalności gospodarczej” [Dz.U. 2003 $\mathrm{Nr} 49$, poz. 408]. Praktyka wskazuje, iż następuje stopniowe zbliżanie się statusu przedsiębiorstwa rolnego i gospodarstwa rolnego (ujęcie funkcjonalne). Należy jednakże podkreślić, że podstawowa różnica polega na tym, że w stosunku do gospodarstw rolnych wyłącza się stosowanie reguł dotyczących funkcjonowania przedsiębiorstw (obowiązek rejestracji, możliwość ogłoszenia bankructwa).

Narzędziem wykorzystywanym do badania funkcjonowania podmiotów gospodarczych jest analiza wskaźnikowa, która umożliwia ocenę porównawczą oraz przyczynową danych pochodzących ze sprawozdań finansowych [Bednarski 1999]. W literaturze przedmiotu wyróżniono kilka grup wskaźników, w tym: płynności, rentowności, obrotowości, zadłużenia, sprawności działania, wspomagania finansowego i rynku kapitałowego. Płynność finansowa określana jako zdolność podmiotów gospodarczych do spłaty na bieżąco zobowiązań uwarunkowana jest przez posiadanie odpowiedniego poziomu płynnych aktywów, których zadaniem jest poprawa sytuacji płatniczej przedsiębiorstw i gospodarstw 
rolnych [Milewska i Wolff 2008]. Zmniejszenie płynności prowadzi bardzo często do zwiększenia rentowności (wzrostu sprzedaży dzięki zwiększeniu udziału zobowiązań wobec dostawców) [Mańko, Sobczyński i Sass 2008]. Rentowność wskazuje, w jakim stopniu aktywa, kapitały własne czy też przychody ze sprzedaży przyczyniają się do generowania zysków. Występuje ona jako zyskowność (w przypadku dodatniego zysku) lub jako deficytowość (kiedy zysk jest ujemny) [Misztal 2015]. Należy jednakże podkreślić, że zmniejszanie płynności finansowej związane $\mathrm{z}$ jednej strony $\mathrm{z}$ problemami w ściaganiu należności, a $\mathrm{z}$ drugiej ze zwiększającym się poziomem zadłużenia ogólnego jest jednym z czynników świadczących o pogorszeniu się sytuacji finansowo-majątkowej podmiotu gospodarczego [Gołębiowski i Tłaczała 2005]. Wskaźnik ogólnego zadłużenia wyrażony jako relacja zobowiązań ogółem do aktywów ogółem wskazuje na całkowity udział zobowiązań w finansowaniu majątku. Wysoki poziom tego wskaźnika świadczy o słabej kondycji finansowej podmiotu gospodarczego [Wypych 2000].

Gospodarstwo rolne ze względu na swoją specyfikę stanowi szczególny rodzaj podmiotu gospodarczego. Charakterystyczny jest dla niego wysoki poziom płynności finansowej [Kisielińska 2003]. W przeprowadzonych badaniach wskazuje się z jednej strony na niewielki wpływ płynności finansowej na rentowność, $\mathrm{z}$ drugiej jednak strony badacze przedmiotu zauważają również, że wzrost płynności finansowej powoduje wzrost efektywności wykorzystania majątku trwałego i obrotowego oraz kapitałów własnych.

\section{Cel i metodyka badania}

Celem badania jest ocena ogólnej sytuacji finansowo-majątkowej polskich gospodarstw rolnych z uwzględnieniem typów oraz wielkości analizowanych podmiotów. Systematyki dokonano zgodnie z metodologią zaproponowaną przez Farm Accountancy Data Network (unijny system zbierania danych rachunkowych FADN). Wyróżniono następujące typy działalności polskich gospodarstw rolnych: uprawy polowe, uprawy ogrodnicze, inne uprawy trwałe, mleczarstwo, inne zwierzęta gospodarskie, gospodarstwa mieszane, różne uprawy i zwierzęta łącznie. Z kolei uwzględniając wielkość ekonomiczną gospodarstw, podzielono je na sześć grup: $2000-<8000,8000-<25000,25000-<50000,50000$ $-<100000,100000-<500000, \geq 500000$ EUR.

W pierwszej części badania wyznaczono wskaźniki analityczne pozwalające na ocenę kondycji polskich gospodarstw rolnych. W tym celu wyznaczono następujące wskaźniki: 
- $\quad$ wskaźnik bieżącej płynności finansowej $\left(W_{B P E}\right)$ jako relację aktywów bieżących do zobowiązań krótkoterminowych,

- $\quad$ wskaźnik ogólnego zadłużenia $\left(W_{z}\right)$ jako sumę zobowiązań gospodarstw rolnych ogółem do aktywów ogółem,

- wskaźniki rentowności aktywów $(R O A)$ oraz rentowności kapitałów własnych $(R O E)$ jako relacja między dochodem gospodarstw rolnych a odpowiednio aktywami i kapitałami własnymi.

Stworzenie syntetycznych wskaźników mające na celu zweryfikowanie postawionej we wstępie opracowania hipotezy głównej zostało przeprowadzone w następujących etapach [Marcinkowska 2007]:

1. Wybrano wskaźniki finansowe (11) do poszczególnych kryteriów oceny a następnie podzielono je dla potrzeb stworzonego modelu na:

- stymulanty:

- $x_{1}$ - wartość dodana netto,

- $x_{2}$ - dochody netto,

- $x_{3}$ - aktywa ogółem,

- $x_{4}$ - przeciętna wartość kapitału własnego,

- $x_{5}$ - wskaźnik bieżącej płynności finansowej,

- $x_{6}$-wskaźnik wydajności pieniężnej,

- $x_{7}$ - rentowność kapitałów własnych,

- $x_{8}$ - rentowność aktywów ogółem,

- destymulanty:

- $x_{9}$ - całkowite koszty,

- $x_{10}$-wskaźnik ogólnego zadłużenia,

- $x_{11}-$ udział zobowiązań krótkoterminowych $\mathrm{w}$ zobowiązaniach ogółem.

2. Dokonano normalizacji wskaźników, stosując wzory:

- stymulanty:

$S_{i j}=x_{i j} / \max x_{i j}$

gdzie:

$x_{i j}$ - wartość $i$-tego miernika dla $j$-tego roku,

max $x_{i j}$ - wartość maksymalna $i$-tego miernika dla $j$-tego roku,

- destymulanty:

$S_{i j}=\min x_{i j} / x_{i j}$

gdzie:

min $x_{i j}$ - wartość minimalna $i$-tego miernika dla $j$-tego roku.

3. Stworzono syntetyczny wskaźnik kondycji finansowej przy założeniu takiego samego wpływu wskaźników na wartość zagregowanego miernika, stosując wzór [Nowak 1995]: 
$S_{j}=\frac{i}{n} \sum_{i-1}^{n} S_{i j}$

gdzie:

$S_{j}$ - zagregowany miernik dla $j$-tego roku,

$n$ - liczba wskaźników wykorzystanych w modelu.

\section{Wyniki i dyskusja}

Wybrane wskaźniki oceny kondycji finansowej polskich gospodarstw rolnych w wybranych latach okresu 2004-2014 z uwzględnieniem wielkości ekonomicznej badanych podmiotów zebrano w tabeli 1 .

\section{Tabela 1}

Wybrane wskaźniki oceny sytuacji finansowej gospodarstw rolnych w latach 2004, 2009 i 2014 według wielkości ekonomicznej

\begin{tabular}{|c|c|c|c|c|c|c|c|}
\hline Lata & $\begin{array}{c}\text { Wskaź- } \\
\text { nik }\end{array}$ & $\begin{array}{c}2000- \\
<8000 \\
\text { EUR }\end{array}$ & $\begin{array}{c}8000- \\
<25000 \\
\text { EUR }\end{array}$ & $\begin{array}{c}25000- \\
<50000 \\
\text { EUR }\end{array}$ & $\begin{array}{c}50000- \\
<100000 \\
\text { EUR }\end{array}$ & $\begin{array}{c}100000- \\
<500000 \\
\text { EUR }\end{array}$ & $\begin{array}{c}\geq 500000 \\
\text { EUR }\end{array}$ \\
\hline 2004 & \multirow{3}{*}{$W_{B P t}$} & 10,30 & 7,24 & 4,90 & 3,94 & 3,09 & 3,02 \\
\hline 2009 & & 16,94 & 9,83 & 5,92 & 4,18 & 3,00 & 3,41 \\
\hline 2014 & & 21,51 & 14,15 & 8,45 & 5,45 & 4,04 & 4,72 \\
\hline 2004 & \multirow{3}{*}{$W_{z}$} & 0,04 & 0,06 & 0,11 & 0,18 & 0,27 & 0,25 \\
\hline 2009 & & 0,01 & 0,03 & 0,06 & 0,10 & 0,18 & 0,22 \\
\hline 2014 & & 0,01 & 0,02 & 0,05 & 0,08 & 0,14 & 0,19 \\
\hline 2004 & \multirow{3}{*}{ ROE } & 0,06 & 0,10 & 0,14 & 0,15 & 0,16 & 0,20 \\
\hline 2009 & & 0,06 & 0,08 & 0,10 & 0,12 & 0,14 & 0,07 \\
\hline 2014 & & 0,06 & 0,08 & 0,10 & 0,13 & 0,16 & 0,07 \\
\hline 2004 & \multirow{3}{*}{$R O A$} & 0,05 & 0,07 & 0,12 & 0,13 & 0,14 & 0,17 \\
\hline 2009 & & 0,03 & 0,04 & 0,05 & 0,06 & 0,08 & 0,06 \\
\hline 2014 & & 0,03 & 0,04 & 0,05 & 0,07 & 0,09 & 0,05 \\
\hline
\end{tabular}

Źródło: Obliczenia własne na podstawie danych FADN.

Polskie gospodarstwa rolne charakteryzują się wysokim poziomem płynności finansowej, niskim poziomem zadłużenia ogólnego oraz niskimi wskaźnikami rentowności kapitałów własnych i aktywów.

Największą płynność $(21,51$ w 2014 r.) i najniższy wskaźnik zadłużenia (10\% w 2014 r.) miały gospodarstwa najmniejsze. We wszystkich analizowanych grupach podmiotów rentowność aktywów i kapitałów własnych była mała. 
W 2014 roku najwyższy poziom wskaźnika $R O E$ wyniósł 16\%, a wskaźnika $R O A-9 \%$ (oba w grupie $100000-<500000$ EUR).

Wybrane dane finansowe z uwzględnieniem typu prowadzonej przez gospodarstwa rolne działalności zamieszczono w tabeli 2.

\section{Tabela 2}

Wybrane wskaźniki oceny sytuacji finansowej gospodarstw rolnych według ich typu w latach 2004, 2006, 2008, 2010, 2012 i 2014

\begin{tabular}{|c|c|c|c|c|c|c|c|c|c|c|}
\hline 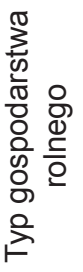 & 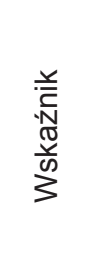 & 2004 & 2006 & 2008 & 2010 & 2012 & 2014 & $\begin{array}{c}\text { Media- } \\
\text { na }\end{array}$ & Max. & Min. \\
\hline 1 & 2 & 3 & 4 & 5 & 6 & 7 & 8 & 9 & 10 & 11 \\
\hline \multirow{6}{*}{ 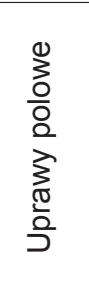 } & $W_{B P t}$ & 3,94 & 3,92 & 3,71 & 5,42 & 7,04 & 6,05 & 5,01 & 7,04 & 3,71 \\
\hline & $W_{w p}$ & 2,90 & 2,84 & 2,17 & 4,33 & 5,57 & 4,89 & 3,78 & 5,57 & 2,17 \\
\hline & $W_{z}$ & 0,15 & 0,17 & 0,16 & 0,07 & 0,08 & 0,07 & 0,12 & 0,17 & 0,07 \\
\hline & $Z_{k} / Z_{o}$ & 0,34 & 0,33 & 0,35 & 0,30 & 0,23 & 0,24 & 0,30 & 0,35 & 0,23 \\
\hline & $R O E$ & 0,15 & 0,13 & 0,12 & 0,18 & 0,19 & 0,12 & 0,15 & 0,19 & 0,12 \\
\hline & $R O A$ & 0,12 & 0,11 & 0,09 & 0,08 & 0,08 & 0,05 & 0,09 & 0,12 & 0,05 \\
\hline \multirow{6}{*}{ 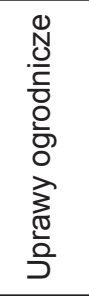 } & $W_{B P t}$ & 3,19 & 2,97 & 2,36 & 2,87 & 2,24 & 2,60 & 2,70 & 3,19 & 2,24 \\
\hline & $W_{w p}$ & 3,30 & 4,02 & 3,19 & 4,97 & 3,71 & 4,91 & 4,02 & 4,97 & 3,19 \\
\hline & $W_{z}$ & 0,25 & 0,21 & 0,24 & 0,14 & 0,15 & 0,15 & 0,19 & 0,25 & 0,14 \\
\hline & $Z_{k} / Z_{o}$ & 0,16 & 0,20 & 0,20 & 0,24 & 0,26 & 0,23 & 0,21 & 0,26 & 0,16 \\
\hline & $R O E$ & 0,10 & 0,13 & 0,10 & 0,16 & 0,13 & 0,16 & 0,13 & 0,16 & 0,10 \\
\hline & $R O A$ & 0,09 & 0,12 & 0,10 & 0,12 & 0,10 & 0,12 & 0,11 & 0,12 & 0,09 \\
\hline \multirow{6}{*}{ 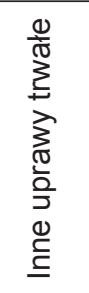 } & $W_{B P t}$ & 6,04 & 5,91 & 4,99 & 4,66 & 8,52 & 5,39 & 5,92 & 8,52 & 4,66 \\
\hline & $W_{w p}$ & 3,84 & 5,13 & 3,78 & 4,47 & 7,75 & 5,87 & 5,14 & 7,75 & 3,78 \\
\hline & $W_{z}$ & 0,09 & 0,10 & 0,12 & 0,07 & 0,05 & 0,05 & 0,08 & 0,12 & 0,05 \\
\hline & $Z_{k} / Z_{o}$ & 0,24 & 0,25 & 0,23 & 0,33 & 0,29 & 0,30 & 0,27 & 0,33 & 0,23 \\
\hline & $R O E$ & 0,05 & 0,08 & 0,06 & 0,10 & 0,11 & 0,05 & 0,07 & 0,11 & 0,05 \\
\hline & $R O A$ & 0,04 & 0,08 & 0,05 & 0,06 & 0,07 & 0,03 & 0,05 & 0,08 & 0,03 \\
\hline \multirow{6}{*}{$\begin{array}{l}0 \\
\sum_{0}^{0} \\
\frac{0}{N} \\
N \\
N \\
D \\
\sum\end{array}$} & $W_{B P t}$ & 4,50 & 5,17 & 5,52 & 6,61 & 7,36 & 7,74 & 6,15 & 7,74 & 4,50 \\
\hline & $W_{w p}$ & 4,67 & 5,61 & 4,97 & 6,37 & 6,12 & 8,23 & 6,00 & 8,23 & 4,67 \\
\hline & $W_{z}$ & 0,10 & 0,10 & 0,10 & 0,06 & 0,06 & 0,05 & 0,08 & 0,10 & 0,05 \\
\hline & $Z_{k} / Z_{o}$ & 0,26 & 0,25 & 0,25 & 0,23 & 0,25 & 0,21 & 0,24 & 0,26 & 0,21 \\
\hline & $R O E$ & 0,12 & 0,14 & 0,11 & 0,14 & 0,13 & 0,11 & 0,13 & 0,14 & 0,11 \\
\hline & $R O A$ & 0,10 & 0,11 & 0,09 & 0,07 & 0,07 & 0,07 & 0,09 & 0,11 & 0,07 \\
\hline
\end{tabular}


Tabela 2 cd.

\begin{tabular}{|c|c|c|c|c|c|c|c|c|c|c|}
\hline 1 & 2 & 3 & 4 & 5 & 6 & 7 & 8 & 9 & 10 & 11 \\
\hline \multirow{6}{*}{ 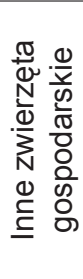 } & $W_{B P t}$ & 15,53 & 6,40 & 9,74 & 7,88 & 10,51 & 11,19 & 10,21 & 15,53 & 6,40 \\
\hline & $W_{w p}$ & 6,85 & 3,37 & 4,43 & 3,78 & 5,44 & 5,26 & 4,85 & 6,85 & 3,37 \\
\hline & $W_{z}$ & 0,04 & 0,04 & 0,07 & 0,05 & 0,04 & 0,03 & 0,05 & 0,07 & 0,03 \\
\hline & $Z_{k} / Z_{o}$ & 0,27 & 0,53 & 0,27 & 0,31 & 0,29 & 0,31 & 0,33 & 0,53 & 0,27 \\
\hline & ROE & 0,06 & 0,09 & 0,07 & 0,07 & 0,10 & 0,07 & 0,08 & 0,10 & 0,06 \\
\hline & $R O A$ & 0,05 & 0,06 & 0,05 & 0,03 & 0,05 & 0,03 & 0,05 & 0,06 & 0,03 \\
\hline \multirow{6}{*}{ 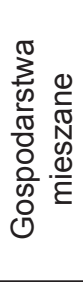 } & $W_{B P t}$ & 5,45 & 4,92 & 6,10 & 5,42 & 7,10 & 7,25 & 6,04 & 7,25 & 4,92 \\
\hline & $W_{w p}$ & 3,87 & 3,81 & 3,91 & 3,73 & 5,14 & 5,91 & 4,39 & 5,91 & 3,73 \\
\hline & $W_{z}$ & 0,12 & 0,13 & 0,12 & 0,10 & 0,10 & 0,09 & 0,11 & 0,13 & 0,09 \\
\hline & $Z_{k} / Z_{o}$ & 0,29 & 0,31 & 0,26 & 0,28 & 0,24 & 0,27 & 0,27 & 0,31 & 0,24 \\
\hline & ROE & 0,14 & 0,13 & 0,11 & 0,15 & 0,17 & 0,15 & 0,14 & 0,17 & 0,11 \\
\hline & $R O A$ & 0,12 & 0,11 & 0,09 & 0,09 & 0,11 & 0,10 & 0,10 & 0,12 & 0,09 \\
\hline \multirow{6}{*}{ 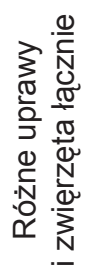 } & $W_{B P t}$ & 7,35 & 7,75 & 7,44 & 8,24 & 9,51 & 9,47 & 8,29 & 9,51 & 7,35 \\
\hline & $W_{w p}$ & 5,13 & 5,04 & 4,24 & 4,83 & 5,05 & 5,09 & 4,90 & 5,13 & 4,24 \\
\hline & $W_{z}$ & 0,05 & 0,06 & 0,07 & 0,04 & 0,04 & 0,04 & 0,05 & 0,07 & 0,04 \\
\hline & $Z_{k} / Z_{o}$ & 0,39 & 0,36 & 0,36 & 0,39 & 0,34 & 0,31 & 0,36 & 0,39 & 0,31 \\
\hline & $R O E$ & 0,10 & 0,10 & 0,08 & 0,11 & 0,11 & 0,07 & 0,09 & 0,11 & 0,07 \\
\hline & $R O A$ & 0,07 & 0,09 & 0,07 & 0,05 & 0,05 & 0,03 & 0,06 & 0,09 & 0,03 \\
\hline
\end{tabular}

Źródło: Obliczenia własne na podstawie danych FADN.

W 2014 roku największą płynność finansową miały gospodarstwa zajmujące się działalnością typu inne zwierzęta gospodarskie $\left(W_{B F}=11,19\right)$, najniższy wskaźnik płynności odnotowano w gospodarstwach zajmujących się uprawami ogrodniczymi $\left(W_{B F}=2,6\right)$. Trend spadkowy wskaźnika płynności odnotowano w przypadku gospodarstw zajmujących się uprawami ogrodniczymi, innymi uprawami trwałymi oraz innymi zwierzętami gospodarskimi. Analizowane podmioty gospodarcze miały stosunkowo dużą wydajność pieniężną (trend ujemny w przypadku gospodarstw zajmujących się innymi zwierzętami gospodarskimi oraz różnymi uprawami i zwierzętami łącznie).

Najwyższy poziom zadłużenia wystąpił w przypadku gospodarstw zajmujących się uprawami ogrodniczymi (przeciętny $W_{z}=0,19$ ). Najniższy poziom zadłużenia miały gospodarstwa zajmujące się innymi zwierzętami gospodarskimi oraz różnymi zwierzętami i uprawami łącznie (przeciętny $W_{z}=0,05$ ). Należy odnotować, że największą wartość, wynosząca 0,39 , wskaźnika udziału zobowiązań krótkoterminowych w zobowiązaniach ogółem w całym analizowanym okresie odnotowano w przypadku różnych upraw i zwierząt łącznie (lata 2004, 2010). Syntetyczne wskaźniki oceny finansowej polskich gospodarstw rolnych według wielkości ekonomicznej zebrano w tabeli 3. 


\section{4}

Tabela 3

Syntetyczne wskaźniki oceny sytuacji finansowej gospodarstw rolnych według ich wielkości ekonomicznej w latach 2004-2014

\begin{tabular}{|c|c|c|c|c|c|c|}
\hline Lata & $\begin{array}{c}2000- \\
<8000 \text { EUR }\end{array}$ & $\begin{array}{c}8000- \\
<25000 \\
\text { EUR }\end{array}$ & $\begin{array}{c}25000- \\
<50000 \\
\text { EUR }\end{array}$ & $\begin{array}{c}50000- \\
<100000 \\
\text { EUR }\end{array}$ & $\begin{array}{c}100000- \\
<500000 \\
\text { EUR }\end{array}$ & $\begin{array}{c}\geq 500000 \\
\text { EUR }\end{array}$ \\
\hline 2004 & 0,50 & 0,64 & 0,69 & 0,72 & 0,73 & 0,75 \\
\hline 2005 & 0,51 & 0,64 & 0,68 & 0,69 & 0,68 & 0,64 \\
\hline 2006 & 0,58 & 0,71 & 0,73 & 0,74 & 0,67 & 0,62 \\
\hline 2007 & 0,68 & 0,77 & 0,79 & 0,80 & 0,83 & 0,64 \\
\hline 2008 & 0,62 & 0,71 & 0,75 & 0,75 & 0,66 & 0,62 \\
\hline 2009 & 0,56 & 0,66 & 0,69 & 0,73 & 0,74 & 0,61 \\
\hline 2010 & 0,67 & 0,79 & 0,82 & 0,85 & 0,85 & 0,71 \\
\hline 2011 & 0,75 & 0,85 & 0,87 & 0,89 & 0,86 & 0,70 \\
\hline 2012 & 0,82 & 0,84 & 0,84 & 0,87 & 0,89 & 0,74 \\
\hline 2013 & 0,66 & 0,82 & 0,84 & 0,86 & 0,87 & 0,70 \\
\hline 2014 & 0,64 & 0,79 & 0,81 & 0,84 & 0,86 & 0,67 \\
\hline
\end{tabular}

Źródło: Obliczenia własne na podstawie danych FADN.

Syntetyczny wskaźnik rozwoju wykazuje dynamikę dodatnią, gdy porównuje się dane z 2014 roku z tymi z 2004 roku, w przypadku pierwszych pięciu grup podmiotów (2000-500 000 EUR). W największych gospodarstwach rolnych odnotowano niewielki trend spadkowy. Przeciętna wielkość wskaźnika syntetycznego oceny kondycji finansowo-majątkowej gospodarstw rolnych $\mathrm{w}$ grupach według wielkości ekonomicznej wyniosła odpowiednio: 0,$4 ; 0,75$; 0,$77 ; 0,79 ; 0,79 ; 0,67$. Najmniejsze przeciętne wartości wskaźnika odnotowano w przypadku gospodarstw najmniejszych $(0,4)$ oraz w gospodarstwach największych $(0,67)$ - rysunek 1 .

Przeciętna wartość wskaźnika syntetycznego w latach 2004-2014 dla gospodarstw zajmujących się uprawami polowymi wyniosła 0,71 , dla upraw ogrodni-

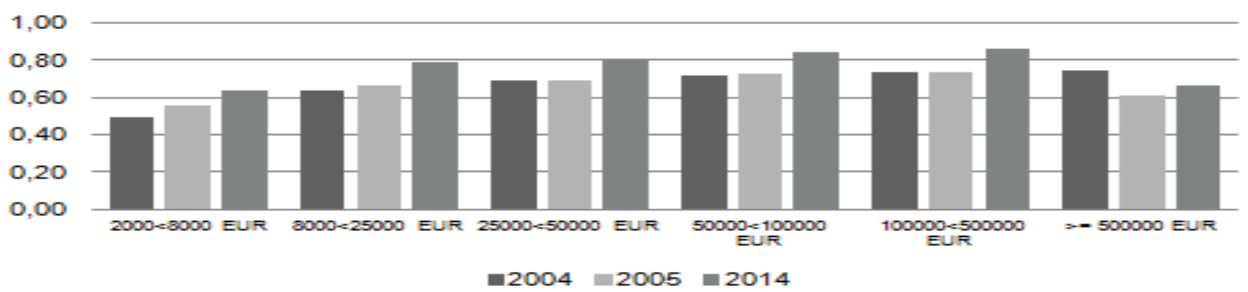

\section{Rysunek 1}

Syntetyczne wskaźniki oceny sytuacji finansowej gospodarstw rolnych według wielkości ekonomicznej w latach 2004, 2005 i 2014

Źródło: Obliczenia własne na podstawie danych FADN. 
czych 0,78 , innych upraw trwałych 0,72 , mleczarstwa 0,73 , innych zwierząt gospodarskich 0,71 , gospodarstw mieszanych 0,71 , a dla różnych upraw i zwierząt łącznie 0,77 (tab. 4).

\section{Tabela 4}

Syntetyczne wskaźniki oceny sytuacji finansowej gospodarstw rolnych według ich typu w latach 2004-2014.

\begin{tabular}{|l|c|c|c|c|c|c|c|c|c|c|c|}
\hline $\begin{array}{l}\text { Typ } \\
\text { gospodarstwa }\end{array}$ & 2004 & 2005 & 2006 & 2007 & 2008 & 2009 & 2010 & 2011 & 2012 & 2013 & 2014 \\
\hline Uprawy polowe & 0,66 & 0,58 & 0,65 & 0,77 & 0,65 & 0,62 & 0,77 & 0,74 & 0,83 & 0,76 & 0,75 \\
\hline $\begin{array}{l}\text { Uprawy } \\
\text { ogrodnicze }\end{array}$ & 0,76 & 0,76 & 0,79 & 0,84 & 0,76 & 0,77 & 0,78 & 0,74 & 0,73 & 0,81 & 0,86 \\
\hline $\begin{array}{l}\text { Inne uprawy } \\
\text { trwałe }\end{array}$ & 0,58 & 0,67 & 0,69 & 0,84 & 0,61 & 0,53 & 0,71 & 0,86 & 0,88 & 0,86 & 0,65 \\
\hline Mleczarstwo & 0,60 & 0,64 & 0,66 & 0,74 & 0,65 & 0,62 & 0,77 & 0,84 & 0,78 & 0,84 & 0,85 \\
\hline $\begin{array}{l}\text { Inne zwierzęta } \\
\text { gospodarskie }\end{array}$ & 0,67 & 0,60 & 0,62 & 0,76 & 0,67 & 0,59 & 0,69 & 0,81 & 0,79 & 0,82 & 0,75 \\
\hline $\begin{array}{l}\text { Gospodarstwa } \\
\text { mieszane }\end{array}$ & 0,62 & 0,59 & 0,58 & 0,56 & 0,59 & 0,73 & 0,69 & 0,76 & 0,87 & 0,87 & 0,90 \\
\hline $\begin{array}{l}\text { Różne uprawy } \\
\text { i zwierzęta } \\
\text { łącznie }\end{array}$ & 0,72 & 0,67 & 0,75 & 0,80 & 0,72 & 0,70 & 0,81 & 0,86 & 0,84 & 0,85 & 0,78 \\
\hline
\end{tabular}

Źródło: Obliczenia własne na podstawie danych FADN.

Największą dynamikę rozwoju (porównując 2014 rok z 2004 rokiem) odnotowano w przypadku gospodarstw mleczarskich $(141,7 \%)$ oraz upraw ogrodniczych $(145,2 \%)$. Najniższą zaś w przypadku upraw polowych $(108,3 \%)$ - rysunek 2.

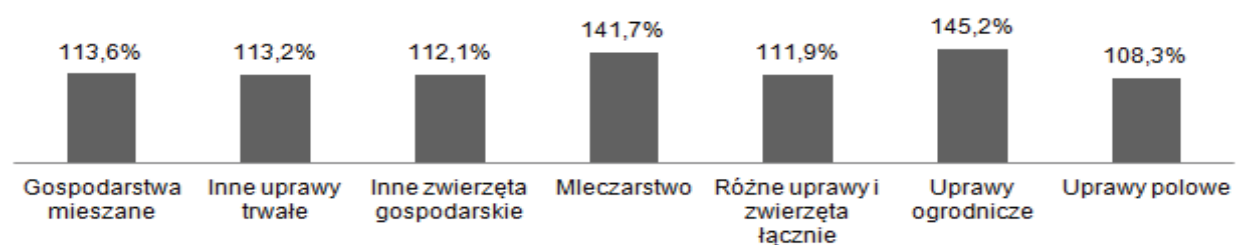

\section{Rysunek 2}

Dynamika rozwoju sytuacji finansowej gospodarstw rolnych w Polsce 2014/2004 Źródło: Obliczenia własne na podstawie danych FADN.

Zgodnie z wyznaczonymi liniami trendu dla syntetycznych wskaźników oceny kondycji gospodarstw rolnych należy zauważyć, że w okresie 2004-2014 wszystkie typy działalności gospodarstw rolnych wykazywały trend dodatni (tab. 5). Największą wartość przed zmienną $x$ odnotowano w przypadku 
mleczarstwa $(0,0246)$, najmniejszą zaś, ale statystycznie nieistotną, dla upraw ogrodniczych $(0,0035)$. Gospodarstwa rolne według wielkości ekonomicznej również wykazują trend dodatni. Najszybciej rozwijają się gospodarstwa o wielkości ekonomicznej $100000-<500000$ EUR. Najwolniej zaś największe gospodarstwa rolne.

Tabela 5

Równania trendu dla syntetycznych wskaźników oceny sytuacji finansowej gospodarstw rolnych w latach 2004-2014

\begin{tabular}{|c|c|c|c|}
\hline \multirow{7}{*}{ 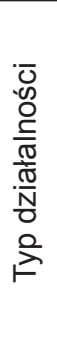 } & Uprawy polowe & $y=0,0158 x+0,6129$ & $R^{2}=0,4524$ \\
\hline & Uprawy ogrodnicze & $y=0,0035 x+0,7613$ & $\mathrm{R}^{2}=0,0797$ \\
\hline & Inne uprawy trwałe & $y=0,0163 x+0,6183$ & $\mathrm{R}^{2}=0,1900$ \\
\hline & Mleczarstwo & $y=0,0246 x+0,5795$ & $\mathrm{R}^{2}=0,7472$ \\
\hline & Inne zwierzęta gospodarskie & $y=0,0172 x+0,603$ & $R^{2}=0,4625$ \\
\hline & Gospodarstwa mieszane & $y=0,0357 x+0,4926$ & $R^{2}=0,8365$ \\
\hline & Różne uprawy i zwięrzęta łącznie & $y=0,0134 x+0,6916$ & $R^{2}=0,4704$ \\
\hline \multirow{6}{*}{ 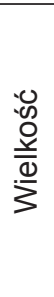 } & $2000-<8000$ & $y=0,0201 x+0,5149$ & $R^{2}=0,4720$ \\
\hline & $8000-<25000$ & $y=0,0191 x+0,6327$ & $R^{2}=0,6464$ \\
\hline & $25000-<50000$ & $y=0,0164 x+0,6755$ & $R^{2}=0,6260$ \\
\hline & $50000-<100000$ & $y=0,0177 x+0,6882$ & $R^{2}=0,6931$ \\
\hline & $100000-<500000$ & $y=0,0211 x+0,6589$ & $R^{2}=0,6065$ \\
\hline & $\geq 500000$ & $y=0,0037 x+0,6504$ & $\mathrm{R}^{2}=0,0611$ \\
\hline
\end{tabular}

Źródło: Obliczenia własne na podstawie danych FADN.

Podsumowując wyniki przeprowadzonego badania, należy odnotować, że sytuacja finansowo-majątkowa polskich gospodarstw rolnych w całym analizowanym okresie była stosunkowo stabilna. Przeprowadzona analiza potwierdziła dotychczasowe wyniki badań dotyczących oceny sytuacji finansowej gospodarstw rolnych. Wysokiemu poziomowi płynności finansowej gospodarstw rolnych towarzyszy niski poziom rentowności. Płynność finansowa warunkowana jest w znacznej mierze przez niskie poziomy zobowiązań bieżących (transfery środków unijnych na rzecz rolnictwa odgrywają tutaj istotną rolę). Problemem gospodarstw rolnych jest niski poziom rentowności wynikający w znacznej mierze ze stosunkowo małych dochodów netto uzyskiwanych z działalności gospodarczej, niskiego poziomu obrotowości majątku.

We wszystkich analizowanych grupach gospodarstw rolnych zaobserwowano w analizie ich dynamiki rozwoju dodatni trend, co oznacza, że należy pozytywnie ocenić ich rozwój. Najniższy przeciętny syntetyczny wskaźnik oceny sytuacji finansowej podmiotów wystąpił w przypadku gospodarstw najmniejszych (2000-8000 EUR) oraz gospodarstw największych ( $\geq 0,5$ mln EUR). Pozostałe 
wartości wskaźników były na zbliżonym poziomie. Sytuacja finansowa gospodarstw rolnych w podziale na typy działalności była również stabilna. Największą dynamikę rozwoju odnotowano w przypadku gospodarstw mleczarskich oraz mieszanych.

Uzyskane wyniki niosą za sobą konieczność odrzucenia postawionej we wstępie opracowania hipotezy głównej: „Gospodarstwa rolne o wielkości ekonomicznej powyżej 0,5 mln EUR charakteryzują się korzystniejszą sytuacją finansowo-majątkową oraz wykazują większą dynamikę rozwoju w porównaniu z mniejszymi podmiotami”. Przeprowadzona analiza uniemożliwia jednoznaczne określenie, która grupa gospodarstw rolnych charakteryzuje się najlepszą kondycją finansową i rozwija się najszybciej. Uzyskana linia trendu dla gospodarstw największych ma najniższy współczynnik nachylenia $(0,0037)$ w porównaniu do reszty analizowanych podmiotów, co świadczy o najmniejszej dynamice poprawy sytuacji finansowej.

Rozwój gospodarstw rolnych uzależniony jest wielu czynników: wewnętrznych (endoagrarnych) i zewnętrznych (egzoagrarnych). Wydaje się jednak, że wielkość gospodarstw czy typ prowadzonej działalności nie są najważniejsza. Wewnętrzne uwarunkowania rozwoju przedsiębiorstw rolnych są ściśle związane z potencjałem produkcyjnym oraz umiejętnością efektywnego i racjonalnego zarządzania nim [Przygodzka 2006]. Współcześni badacze przedmiotu w znacznej większości stoją na stanowisku, iż o rozwoju gospodarstw rolnych w podstawowej mierze decydują czynniki o charakterze egzogenicznym [Miś 2009]. Do czynników tych należy zaliczyć: uwarunkowania rynkowe, instytucjonalne, środowiskowe, regionalne, makroekonomiczne i globalne. Do najważniejszych determinant zewnętrznych zalicza się: poziom PKB oraz udział rolnictwa w PKB, poziom wydatków na żywność oraz dochód do dyspozycji, poziom handlu zagranicznego.

\section{Podsumowanie}

Gospodarstwa rolne są szczególnym rodzajem podmiotów gospodarczych, których podstawowym celem, podobnie jak przedsiębiorstw, jest maksymalizacja zysku. Prowadzona przez gospodarstwa rolne działalność przynosi wymierne rezultaty, a podejmowane przez ich zarządzających działania mają wpływ na kształtowanie się wyników finansowych oraz znajdują swoje odzwierciedlenie we wskaźnikach finansowych. Polskie gospodarstwa rolne charakteryzują się stabilną sytuacją finansowo-majątkową. Ich problemem jest niski poziom rentowności aktywów i kapitałów własnych. Syntetyczny wskaźnik oceny kondycji finansowej gospodarstw rolnych wskazuje na ich stabilną sytuację oraz niewielki, 
dodatni trend rozwojowy. Uzyskane wyniki badania nie pozwoliły jednoznacznie określić, który rodzaj czy też wielkość ekonomiczna gospodarstw rolnych charakteryzuje się najlepszą kondycją finansową. W związku z tym odrzucono postawioną hipotezę główną.

\section{Literatura}

BEDNARSKI L., 1999: Analiza finansowa w przedsiębiorstwie, Polskie Wydawnictwo Ekonomiczne, Warszawa.

BUDZINOWSKI R., SUCHOŃ A., 2015: Relacja gospodarstwa rolnego i przedsiębiorstwa rolnego w świetle publicznych mechanizmów ich wspierania, [w:] P. Litwiniuk (red.), Prawne mechanizmy wspierania i ochrony rolnictwa rodzinnego $w$ Polsce i innych państwach Unii Europejskiej, Fundacja Programów Pomocy dla Rolnictwa FAPA, Warszawa.

GOŁĘBIOWSKI G., TŁACZAŁA A., 2005: Analiza ekonomiczno-finansowa w ujęciu praktycznym, Difin, Warszawa.

KISIELIŃSKA J., 2003: Wykorzystanie metod wielowymiarowej analizy do oceny sytuacji finansowej gospodarstw rolniczych, Wieś i Rolnictwo 4(121), 80-93.

MAŃKO S., SOBCZYŃSKI T., SASS R., 2008: Zmiany poziomu zrównoważenia plynności finansowej $w$ gospodarstwach rolniczych UE w latach 1989-2005, Zeszyty Naukowe SGGW - Ekonomika i Organizacja Gospodarki Żywnościowej 64, 5-22.

MARCINKOWSKA M., 2007: Ocena działalności instytucji finansowych, Difin, Warszawa.

MILEWSKA A., WOLFF A., 2008: Kształtowanie płynności finansowej na przykładzie przedsiębiorstwa przemystu chemicznego, Zeszyty Naukowe SGGW - Ekonomika i Organizacja Gospodarki Żywnościowej 64, 175-187.

MISZTAL A., 2015: Analiza rentowności spółek przemystu surowcowego indeksu WIG20, Nauki o Finansach 2(23), 96-109.

MIŚ T., 2009: Specyficzne uwarunkowania prowadzenia gospodarstw przez młodych rolników, Zeszyty Naukowe SGGW - Ekonomika i Organizacja Gospodarki Żywnościowej $75,149-160$.

NOWAK E., 1995: Rachunkowość menedżerska, Wydawnictwo Akademii Ekonomicznej im. Oskara Lanego we Wrocławiu, Wrocław.

PRZYGODZKA R., 2006: Fiskalne instrumenty wspierania rozwoju rolnictwa - przyczyny stosowania, mechanizmy i skutki, Wydawnictwo Uniwersytetu w Białymstoku, Białystok.

RYCHLIK T., KOSIERADZKI M., 1978: Podstawowe pojęcia $w$ ekonomice rolnictwa, PWRiL, Warszawa.

SADOWSKI A., 2009: Gospodarstwa rolne w koncepcji polityki zrównoważonego rozwoju obszarów wiejskich, Journal of Agribusiness and Rural Development 2(12), 167-173.

SIERPIŃSKA M., JACHNA T., 1998: Ocena przedsiębiorstwa wedtug standardów światowych, PWN, Warszawa.

Ustawa z dnia 23 kwietnia 1964 r. - Kodeks cywilny. Dz.U. 1964 nr 16, poz. 93 z późn. zm.

WYPYCH M., 2000: Finanse przedsiębiorstwa z elementami zarzadzania i analizy, Absolwent, Łódź

ZEGAR J.St., 2012: Wspótczesne wyzwania rolnictwa, PWN, Warszawa. 


\begin{abstract}
Abstrakt
Podstawowym celem artykułu jest ocena rozwoju sytuacji finansowo-majątkowej polskich gospodarstw rolnych. Początkowe rozważania poświęcono teoretycznym zagadnieniom związanym z gospodarstwami rolnymi oraz czynnikami wpływającymi na ich bieżącą sytuację finansowo-majątkową i rozwój. Właściwą część opracowania poświęcono empirycznej weryfikacji hipotezy głównej. Wyznaczono wskaźniki analityczne i syntetyczne dla gospodarstw rolnych, a następnie wysnuto wnioski końcowe.
\end{abstract}

Słowa kluczowe: gospodarstwa rolne, sytuacja finansowo-majątkowa

\title{
Evaluation of the financial and assets situation of Polish farms in 2004-2014
}

\begin{abstract}
The main aim of this article is to show the development of the financial and assets situation of Polish farms. Initial reflections were devoted to theoretical issues related to agricultural holdings and factors influencing their current financial and wealth situation and development. The actual part of the study was devoted to the empirical verification of the main hypothesis. Analytical and synthetic indicators for agricultural holdings were determined and the final conclusions were drawn.
\end{abstract}

Key words: farms, financial and property situation 